\title{
State Regulation of Cryptocurrencies as a Factor of Regional Development
}

\author{
Kovalyova N.N.* Zhirnova N.A. Filimonova M.V.
}

\author{
Federal State-Funded Educational Institution of Higher Education "Saratov State Law Academy," Saratov 410056, \\ Russian Federation, \\ *Corresponding author. Email: kovaleva.natalia@mail.ru
}

\begin{abstract}
The main attention is paid to the review of prospects in the field of legal regulation of such new financial instruments as cryptocurrencies as a type of electronic money. A number of bills and laws governing the public relations in question are analyzed. The problems that the Russian legislator is required to solve in order to ensure adequate legal regulation of new public relations are highlighted. The experience of some foreign countries in the field of legal regulation of cryptocurrencies is analyzed. It is concluded that today the development of the legal regime of new financial instruments, cryptocurrencies, is an urgent need. The lack of state regulation in the Russian Federation of electronic payments made in payment systems that use cryptocurrency as a means of transactions introduces confusion into society making the use of digital financial assets in the Russian Federation doubtful, which seems like a denial of world technology. Ultimately, the development of the Russian state depends on the fastest solution to this problem.

Keywords: cryptocurrency, blockchain, digital financial asset, digital rights, token, electronic money
\end{abstract}

\section{INTRODUCTION}

Over the past few years, in the Russian Federation, an object such as cryptocurrency has caused legal dissonance regarding its nature and determination of its property. Article 128 of the Civil Code of the Russian Federation contains a list of objects of civil rights, the circulation of which is regulated in the state. They include:

- items, including cash and documentary securities;

- other property, including cashless funds, uncertificated securities, property rights, digital rights;

- results of work and provision of services;

- protected results of intellectual activity and equivalent means of individualization (intellectual property); and

- intangible values [1].

However, cryptocurrency does not possess the signs of any particular object from those specified in Article 128 of the Civil Code of the Russian Federation. Due to the fact that the legislative definition of a cryptocurrency or an object possessing its attributes is not enshrined, this raises many questions in the economic and legal fields, for example, is it possible to use such an object by any person (without giving the subject special status); is such an object recognized as a means of payment; whether cryptocurrency is subject to accounting; does tax legislation apply to such an object and many other questions.

Statistics on the use of various types of cryptocurrencies in the world (2018)

\section{RESEARCH METHODOLOGY}

This study is an analysis of the standards of Russian information law that regulate current problems against the background of the growing role of information technology in the modern world.

The study analyzed more than 20 sources of various levels on the development and implementation of state regulation of the legal nature of cryptocurrency as a type of electronic money.

The authors used the following research methods:

- formal-legal, when indicating signs and analyzing the definition of "cryptocurrency" and "electronic money";

- comparative method, when comparing the legal regulation of access to this type of information and its use;

- structural analysis method, when studying an object, its specific features are analyzed as a structural element included in a more general concept (a more general concept with respect to the concept of "cryptocurrency" is the concept of "electronic money"). Using this method, the authors proposed an introduction of the concept of "cryptocurrency" to Russian legislation; and

- information approach, when studying any object, process, or phenomenon in nature or society; the first goal is to identify and analyze the most specific information aspects that substantially determine their current state and development. 


\section{RESEARCH RESULTS}

The following authors tried to determine the legal nature of cryptocurrency in their papers, L.A. Novosyolova, A.I. Saveliyev, R.M. Yankovsky, and others.

L.A. Novosyolova in her paper cited the main characteristics of Bitcoin, to which the following were attributed:

- Bitcoin exists in the form of an electronic record;

- its value is determined by the market;

- distributed way of storing information (there is no centralized storage);

- Bitcoin is issued as a result of mining;

- this is an exhaustible resource (it is possible to issue only 21 million coins);

- transactions are not subject to cancellation;

- division of one unit to one hundred-millionth part;

- open registry of actions; and

- low transaction costs, in comparison with other payment systems [2].

Any cryptocurrency possesses the listed features, possibly, with the exception of limited quantity and such a small division. Trying to correlate the selected features with the features of existing objects of civil rights, the following result was obtained:

- this is not an item since it does not have a tangible form of presentation;

- this is not money (such a definition of cryptocurrency would be contrary to Article 27 of the Law on the Central Bank, which states that the ruble is recognized as the official currency in the Russian Federation and the introduction of other currency units is not allowed [3]);

- this is not a paperless security since it does not meet the general provisions on a paperless security contained in Article 149 of the Civil Code of the Russian Federation; in addition, according to Clause 2 of Article 142 of the Civil Code of the Russian Federation, a security may only be recognized as an object that is named as such in the law or recognized as such in the manner prescribed by law [4];

- this is not the results of work and provision of services since there is no obligation between the participants in the system;

- these are not protected results of intellectual activity and equivalent means of individualization (intellectual property) since all operations are performed using technical software protocols and there is no creative component; and

- they are not intangible values since they do not relate to objects that are closely related to the person.

Due to the complexity of determining the legal nature and the lack of mention of cryptocurrencies in Article 128 of the Civil Code of the Russian Federation, some scholars have proposed banning their use in the territory of the Russian Federation [5]. However, the specified article (128 of the Civil Code of the Russian Federation) does not indicate information as an object, although it is actually used as a product in civil matters. However, since such information should constitute value, this leads us to the concept of electronic means of payment. The position of the legislator that only cash is related to electronic means of payment [6], as mentioned above, excludes the attributing of cryptocurrencies to them.

Cryptocurrency is not electronic money as well. According to the concept of "electronic money" enshrined in the Directive, electronic money is issued by a participant in the system upon receipt of funds, which does not apply to cryptocurrency. This is due to several reasons: firstly, the determination of the value of cryptocurrency is impossible due to the absence of exchange rate since such an object is not recognized by any country as a legal means of payment, which means it does not fall under the scope of Federal Law No.173-FZ 12/10/2003 “On Currency Regulation and Currency Control," second, the value is credited to a personal account in the system in two ways, receiving an electronic payment from another counterpart in the system or receiving remuneration for securing a transaction, in the form of a set of characters obtained by solving a computational problem using technical means (mining).

Speaking about the impossibility of defining cryptocurrency as electronic money, it should be mentioned that the payment system includes an issuer, as a rule, with the status of a credit organization, other organizations, partners, between which an electronic payment is made using systemic means of payment, and users. In a system that uses cryptocurrency as a means of payment, the first two subjects are absent. A personal account is opened to a user person, the status of which is hard to determine (the absolute anonymity casts doubt on the example described by L.A. Novosyolova, the case of an anonymous online trading platform known as the Silk Road [7]), which once again confirms the uniqueness of such a system.

Another circumstance that makes it difficult to regulate payment systems making electronic payments using cryptocurrencies is their global nature. Such systems are used in the territory of almost all countries, and in addition to the uncertainty of the question of whether the legislation of the country applies to the transaction (whether the subjects are residents; in the territory of which country the payment is made, etc.), there are no general principles of legal regulation due to economic features, the development degree of technology and law, of different countries.

"Other property" remains the only object not considered, included in Article 128 of the Civil Code of the Russian Federation. We believe that talking about cryptocurrency as about other property does not make sense since this definition is a pointer to an open list of civil rights objects and does not exist as an object endowed with features specific to it. Otherwise, the expression of one poorly studied object through an uncertain another one will not lead to an understanding of the concept.

Another generalizing but not enshrined at the legislative level object for such means of payment that are not issued by the state are "private money" described in the paper of Friedrich A. Hayek. Until the 19th century, the state's monopoly on the issue of money was the exception rather 
than the rule [8]; private money was a banknote (a document, usually a bill) confirming the size of the claim on the issuer. Such a definition resembles the concept of electronic means of payment but the difference is that information about the cost (amount of claim) was reflected on paper, instead of an electronic file. Issuers could be banks, railway companies, construction companies, and others, those who could issue a large number of such documents secured by money. A.I. Saveliyev says that the modern development of cryptocurrencies can be considered as a return to the era of free banking at a new technological revolution. By free banking, he understands the issue of money by various banks on a competitive basis, which was typical for the cash circulation of most developed countries in the period 13-19 centuries [9].

L.A. Novosyolova proposes the following concept of Bitcoin, "it is a binding right of claim arising based on an agreement between counterparts in the relevant settlement system" [10]. R.M. Yankovsky does not consider cryptocurrency as a requirement, justifying that the lack of a centralized depository precludes the possibility of presenting a claim to anyone [11]. The absence of the issuer and the impossibility of presenting a claim to it is logical. For example, the issuer acts as an intermediary in the banking payment system, receiving value from one and distributing it to another. In a system, in which cryptocurrency acts as a means of payment, counterparts distribute these values without an intermediary. We believe that the consideration of cryptocurrency through the very prism of a means of payment is the most correct. A counterargument to the fact that the determination of cryptocurrency through the right of claim is impossible due to the absence of a depository will be that the claim is presented not to the issuer of the system but to all participants of the system. The system has no subjects other than counterparts to interact with. Drawing an analogy with electronic money, which is a right of claim, it should be mentioned that in addition to collecting money from the issuer, electronic payments implying the exchange of payment methods between users and their redistribution in the system are made, which indicates the emergence of relationships between counterparts, and the subject themselves determine what fair legal fact lies at the base of these relations (fulfillment of obligations under the contract, donation, etc.).

Currently, according to Article 27 of the Law on the Central Bank, private money is a money equivalent, the circulation of which is prohibited in the state. This understanding is supported by the courts when considering administrative cases of a special proceeding on recognition of information prohibited for distribution. They unequivocally expressed the position that cryptocurrency is a money equivalent [12].

It follows from the decisions of the courts reviewing civil disputes that all adverse consequences arising and having the opportunity to manifest themselves are borne by a person who consciously performs an operation using cryptocurrency. The Ryazhsky District Court of the Ryazan Oblast issued a decision dated 04/26/2017 in the case 2-160/2017; within the framework of this case,
M.N. Bushayev filed a lawsuit in court to protect consumer rights, in which he indicated that the individual entrepreneur Boyarkin R.V. rendered him a Bitcoin cryptocurrency exchange service poorly. The court, pointing out that there is no legislative regulation of cryptocurrency as an object of civil rights, considered the plaintiff's claims insolvent and refused to satisfy the stated claims. In the ruling of the Arbitration Court of the Tyumen Oblast dated 06/22/2016 in the case A70$15360 / 2016$, the court called the actions of the debtor unscrupulous due to the use of borrowed funds to purchase cryptocurrency.

Such approaches of the courts seem unfair since the relations that develop when performing various types of actions with cryptocurrency exclude the application of the rules of law to them, which deprives any legal protection.

The Ninth Arbitration Court of Appeal took the first step towards classifying cryptocurrencies as part of the bankruptcy case, attributing it to other property by reference to draft Federal Law No.424632-7. This document marks the beginning of filling the legislative gap since the refusal, with reference to the absence of a regulatory framework, was deemed as the false one by the second instance. In the ruling of the Moscow Arbitration Court dated 03/05/2018 in the case NA40-124668/17-71$160 \mathrm{~F}$, the court did not include cryptocurrency in the bankruptcy asset, having referred to the absence of attributing it to any object provided for in the legislation, because of which the rule of the analogy of law is not applicable. This judicial act was canceled by the Decree of the Ninth Arbitration Court of Appeal dated 05/07/2018 in this case.

Courts interpreted cryptocurrency negatively due to the Information of the Bank of Russia dated 01/27/2014 "On the Use of "Virtual Currencies" in Transactions, Particularly, Bitcoin" (published in the Bank of Russia Bulletin, No. 11 dated 02/05/2014) and Rosfinmonitoring Information Message "On the Use of Cryptocurrencies," which expressly state that cryptocurrency is a money equivalent and transactions concluded using them can be attributed to transactions (operations) aimed at legalizing (laundering) of proceeds from crime and financing terrorism [13].

After that, the Federal Tax Service denied the findings of the Bank of Russia in a letter, indicating that the law does not prohibit the use of cryptocurrency in the territory of the Russian Federation [14].

There was no other legislation, there were only separate clarifications on issues published by the Ministry of Finance, for example, "On the Regulation of the Issue and Circulation of Cryptocurrencies" [15] and by the Federal Tax Service ("On the Control of the Circulation of Cryptocurrencies (Virtual Currencies)" [16].

Until recently, these were the only regulations governing the circulation of cryptocurrencies in the territory of the Russian Federation. In connection with the approval of the List of Instructions following the meeting on the use of digital technologies in the financial sector [17], two bills were prepared: 
- Draft Federal Law No. 419059-7 “On Digital Financial Assets" [18];

- Draft Federal Law No. 373645-7 “On the System of Distributed National Mining" (submitted to the State Duma of the Russian Federation on 01/25/2018).

These bills were subject to negative criticism from specialists in the field of cryptocurrency research.

Many comments were made about the first bill. Thus, the opinion of the State Duma Committee on Information Policy, Information Technologies, and Communications stated that some of the concepts introduced already exist in the existing legislation, and this bill does not indicate a solution to this problem [19]; the opinion of the State Duma Committee on the Financial Market stated that the definition of a digital financial asset as the property is incorrect and the bill does not reflect the solution of many issues existing in the financial and legal area [20]; other disadvantages were as well indicated in the opinion of the Committee on Economic Policy, Industry, Innovative Development, and Entrepreneurship No. 3.8/522 dated April 3, 2018, and in the official comment of the Government of the Russian Federation No.2968p-P10 dated April 19, 2018.

The second bill was returned with the reference to the need for additional state funding to implement such a bill [21]. This document proposed to legalize only the state-owned cryptocurrency, cryptoruble. It follows from the meaning of this document that the author proposed the creation of a bank payment system using Blockchain technology and the means of payment used would be cryptoruble.

Both bills proposed defining cryptocurrency as a digital financial asset. It is possible that introducing into the legal circulation of a new object for regulation such complex relations will help resolve the current situation but such an introduction should be made by a more elaborated bill.

Federal Law No. 34-FZ "On Amending Parts One, Two, and Article 1124 of Part Three of the Civil Code of the Russian Federation" [22] (the so-called "Digital Rights Act") was adopted in March 2019.

This statutory act makes the following changes to the Civil Code of the Russian Federation: first, it enshrines such a definition as the "digital right," which is a basic one. Digital rights are mandatory and other rights, the content and conditions for the implementation of which are determined in accordance with the rules of the information system that meets the criteria established by law. The implementation, disposal, including transfer, pledge, encumbrance of digital right in other ways or restriction of the disposal of the digital right are possible only in the information system without contacting the third party. Digital rights are now objects of civil rights in accordance with the provisions of Article 128 of the Civil Code of the Russian Federation. Second, to simplify the process of making transactions with digital rights, an expression of one's will is equated to a simple written form of a transaction using electronic or other similar technical means (using a smartphone or sending SMS, for example). Third, smart contracts ("self-executable" transactions) are regulated. Four, the law resolves the issue of legalizing the collection and processing of large amounts of information in anonymized form ("Big Data").

Unfortunately, the new financial instruments under consideration are increasingly being used in a criminal environment, i.e in the commission of corruption crimes, in the sale of narcotic and psychoactive substances and pornography. Most often, these actions are carried out on the illegal Internet (Darknet).

There are three main sectors of crypto crime: - illegal sale of psychoactive substances (narcotic drugs, psychotropic substances, etc.), other prohibited goods, content, or services; - laundering of criminal proceeds using the new digital currency; - theft of cryptocurrency and other crimes against property [23].

\section{DISCUSSING THE RESULTS}

Consolidation in Article 128 of the Civil Code of the Russian Federation of digital rights as an object of civil rights, as well as a concept of digital rights in Article 141.1 of the Civil Code of the Russian Federation, allows the courts to apply the analogy of law, instead of being guided only by principles, which would form the base of good judicial practice.

Unfortunately, administrative and legal regulation today reduces only to by-laws of economic bodies. Thus, the Information of the Bank of Russia dated 09/04/2017 "On the Use of Private "Virtual Currencies" (Cryptocurrencies)," in which the Central Bank is not as categorical as in the previous letter, indicating the high risks of financial losses when using cryptocurrencies, is currently in effect. There are also various clarifications from government bodies, particularly, as follows: the Letter of the Department of Tax and Customs Policy of the Ministry of Finance of Russia No. 03-03-06/1/8061 dated February 9, 2018; the Letter of the Ministry of Finance of Russia No. 03-04-05/20048 dated March 03/29/2018 “On Personal Income Tax with Respect to Income from Transactions for the Purchase and Sale of Bitcoins"; the Letter of the Ministry of Finance of Russia No. 03-0306/1/8061 dated 02/09/2018 "On Accounting for the Purposes of Tax on Profit of Cryptocurrency Received as a Result of Settlements (Barter)," and others.

To create a full-fledged regulatory framework, it is required to draw attention to the experience of other countries that have already determined the status of cryptocurrencies in their jurisdiction. Thus, Australia and the UK define cryptocurrency as a digital currency but not related to financial assets; China considers it a commodity; Japan, as a value; the USA consider it as an analog of money, property, and digital goods; since 2013, Sweden treats cryptocurrency as a currency; and Germany uses it as a legal means of settlement. The Republic of Belarus understands cryptocurrency as bitcoin, another digital sign (token) used in international circulation as a universal medium of exchange. There are also countries that have a negative attitude to a digital financial asset and that are not ready to recognize it as a legal object. These countries include Denmark, Hong Kong, Ukraine, etc. [24]. 
[12] Resheniye Narimanosvskogo rayonnogo suda

\section{CONCLUSIONS}

The lack of legislative regulation in the Russian Federation of electronic payments made in payment systems that use cryptocurrency as a means of transactions introduces confusion into society making the use of digital financial assets in the Russian Federation doubtful, which seems like a denial of world technology. This result leads to a huge legal gap, which, as a result, may cause the development of the shadow economy and an increase in the number of crimes committed using cryptocurrencies.

\section{REFERENCES}

[1] Grazhdanskiy kodeks Rossiyskoy Federatsii (chast' pervaya) ot 30.11.1994 No. 51-FZ (red. ot 16.12.2019), Sobraniye zakonodatel'stva RF, 05.12.1994, No. 32, st. 3301

[2] L.A. Novoselova, O pravovoy prirode bitkoyna, Khozyaystvo i pravo, 9 (2017).

[3] Federal'nyy zakon ot 10.07.2002 N 86-FZ (red. ot 07.03.2018) «O Tsentral'nom banke Rossiyskoy Federatsii (Banke Rossii)» (red. ot 27.12.2019) // Sobraniye zakonodatel'stva RF, 15.07.2002, No. 28, st. 2790 .

[4] A.I. Savelyev, Kriptovalyuty v sisteme ob"yektov grazhdanskikh prav , J.«Zakon», 8 (2017).

[5] K. Nikitin, Zakonodatel'nyye novelly pravovogo regulirovaniya obrashcheniya kriptovalyut, Rynok tsennykh bumag, 7 (2016).

[6] Federal'nyy zakon ot 27.06.2011 No. 161-FZ (red. ot 27.12.2019) «O natsional'noy platezhnoy sisteme» // «Sobraniye zakonodatel'stva RF», 04.07.2011, No. 27, st. 3872

[7] L.A. Novoselova, O pravovoy prirode bitkoyna, Khozyaystvo i pravo, 9 (2017).

[8] R.M. Yankovskiy, Gosudarstvo vs. Bitkoin, Business Excellence, 11 (2017).

[9] A.I. Savel'yev, Kriptovalyuty v sisteme ob"yektov grazhdanskikh prav, Zakon, 8 (2017).

[10] L.A. Novoselova, O pravovoy prirode bitkoyna, Khozyaystvo i pravo, 9 (2017).

[11] Yankovskiy R.M. Gosudarstvo i kriptovalyuty: problemy regulirovaniya, Moskovskiy gosudarstvennyy universitet, $2017 . \quad$ URL: http://msu.edu.ru/papers/yankovskiy/blockchain.pdf
Astrakhanskoy oblasti ot 15.08 .2017 g. po delu $2 \mathrm{a}$ 703/2017; Resheniye Zheleznodorozhnogo rayonnogo suda g. Krasnoyarka ot 18.08.2016 g. po delu No.24283/2016; Resheniye Petrogradskogo rayonnogo suda g. Sankt-Peterburg ot 17.07.2017 g. po delu No.2$3434 / 2017$.

[13] Informatsiya Banka Rossii ot 27.01.2014 «Ob ispol'zovanii pri sovershenii sdelok «virtual'nykh valyut», v chastnosti, Bitkoyn», «Vestnike Banka Rossiya, N 11.

[14] Vopros: O kontrole za obrashcheniyem kriptovalyut (virtual'nykh valyut).(Pis'mo FNS Rossii ot 03.10.2016 No. OA-18-17/1027), SPS «Konsul'tant Plyus»» URL: http://www.consultant.ru/cons/cgi/online.cgi?req=doc;b ase=QUEST;n=162766\#0482703680291398.

[15] Vopros: O regulirovanii vypuska i oborota kriptovalyut.(Pis'mo Minfina Rossii ot 02.10.2017 No. 03-11-11/63996), SPS «Konsul'tantPlyus» URL: http://www.consultant.ru/cons/cgi/online.cgi?req=doc\& base $=$ QUEST\&n=171502\#0134426346605512.

[16] Vopros: O kontrole za obrashcheniyem kriptovalyut (virtual'nykh valyut). (Pis'mo FNS Rossii ot $03.10 .2016 \quad \# \quad$ OA-18-17/1027), SPS «Konsul'tantPlyus» URL: http://www.consultant.ru/cons/cgi/online.cgi?req=doc;b ase $=$ QUEST; $\mathrm{n}=162766 \# 08837431109105303$.

[17] Perechen' porucheniy po itogam soveshchaniya po voprosu ispol'zovaniya tsifrovykh tekhnologiy $\mathrm{v}$ finansovoy sfere (utv. Prezidentom RF 21 oktyabrya 2017 g. \# $\quad$ Pr-2132, URL: http://kremlin.ru/acts/assignments/orders/55899.

[18] Proyekt federal'nogo zakona «O tsifrovykh finansovykh aktivakh» (opublikovan 25.01.2018), https://www.minfin.ru/ru/search/?q_4=\%D0\%BE+\%D1 $\% 86 \% \mathrm{D} 0 \% \mathrm{~B} 8 \% \mathrm{D} 1 \% 84 \% \mathrm{D} 1 \% 80 \% \mathrm{D} 0 \% \mathrm{BE} \% \mathrm{D} 0 \% \mathrm{~B} 2$ $\% \mathrm{D} 1 \% 8 \mathrm{~B} \% \mathrm{D} 1 \% 85+\% \mathrm{D} 1 \% 84 \% \mathrm{D} 0 \% \mathrm{~B} 8 \% \mathrm{D} 0 \% \mathrm{BD} \% \mathrm{D}$ 0\%B0\%D0\%BD\%D1\%81\%D0\%BE\%D0\%B2\%D1\%8 B $\%$ D1\%85+\%D0\%B0\%D0\%BA\%D1\%82\%D0\%B8\% D0\%B2\%D0\%B0\%D1\%85\&source_id_4=6

[19] Zaklyucheniye na proyekt federal'nogo zakona No. 419059-7 «O tsifrovykh finansovykh aktivakh», vnesennyy deputatami Gosudarstvennoy Dumy A.G.Aksakovym, I.B.Divinskim, O.A.Nikolayevym, R.M.Mardanshinym, A.A.Gettoy, M.L.Shakkumom, A.B.Vybornym, K.G.Slyshchenko, Ye.B.Shulepovym, V.I.Afonskim, N.D.Boyevoy, I.Ye.Mar'yash, 
A.I.Voyevodoy,

S.V.Zheleznyakom, S.A.Vostretsovym, A.V.Chernyshevym, chlenami
Soveta Federatsii N.A.Zhuravlevym, A.N.Yepishinym, V.V.Poletayevym,

URL:http://sozd.parlament.gov.ru/bill/419059-7.

[20] Zaklyucheniye po proyektu federal'nogo zakona No. 419059-7 «O tsifrovykh finansovykh aktivakh», vnesennomu deputatami Gosudarstvennoy Dumy A.G. Aksakovym, I.B. Divinskim, O.A. Nikolayevym, chlenom Soveta Federatsii N.A. Zhuravlevym, URL:http://sozd.parlament.gov.ru/bill/419059-7

[21] Otvet Pravovogo upravleniya na sootvetstviye trebovaniyam stat'i 104 Konstitutsii RF,
URL:http://sozd.parlament.gov.ru/bill/419059-7 (data obrashcheniya 17.03.2020 g.)

[22] Sobraniye zakonodatel'stva RF. 25.03.2019. No. 12. S t. 1224

[23] S.V. Ivantsov, E.L. Sidorenko, B.A. Spasennikov, Yu.M. Berezkin, Ya.A. Sukhodolov, Prestupleniya, svyazannyye $\mathrm{s}$ ispol'zovaniyem kriptovalyuty: osnovnyye kriminologicheskiye tendentsii, Vserossiyskiy kriminologicheskiy zhurnal, 1(2019) 86.

[24] V. Kislyy, Yuridicheskiye aspekty primeneniya blokcheyna i ispol'zovaniya kriptoaktivov, URL: https://vk.com/doc138034131_447893385?hash=d1a50 $518 \mathrm{fa} 0 \mathrm{f} 96 \mathrm{fa} 39 \& \mathrm{dl}=84 \mathrm{~cd} 63520 \mathrm{a} 670 \mathrm{ec} 810$. 